\title{
5. 'We're tired from talking': The native title process from the perspective of Kaanju People living on homelands, Wenlock and Pascoe Rivers, Cape York Peninsula
}

\section{David Claudie}

This paper investigates the native title process from the perspective of Kaanju families living on our traditional homelands at Chuulangun on the upper Wenlock River in central Cape York Peninsula, Northern Australia. Our experiences reinforce our view that the native title process and the structures it upholds are at odds with Indigenous land tenure and governance systems, that they create and maintain obstacles for the carrying out of on-ground Indigenous land and resource management aspirations and obligations, and that they work against the homelands development and economic development aspirations of Kaanju Traditional Owners living on homelands. This paper draws particularly on the experiences of core Kaanju families with a native title claim to some 241000 hectares of our homelands centred on the Wenlock River in central Cape York, locally known as the Batavia Claim. This claim was lodged with the National Native Title Tribunal in 1997 and eight years on 'we're tired from talking' ${ }^{1}$ and engaging in a process that works on the assumption that we have to justify and prove our ownership of homelands, while government and other 'stakeholders' presume control over our traditional lands.

This paper stresses three main points. First, our frustration with a native title process that has:

- accommodated the 'interests' of the State government and other 'stakeholders' to the detriment of our rights as Traditional Owners of our lands under claim, and

\footnotetext{
1 This paper is dedicated to my Aunty, a Kaanju woman (my father's father's younger brother's daughter), who sadly passed away in December 2003. I often heard her, along with a number of other Senior Aboriginal people bemoan 'we're tired from talking' when not seeing any progress for their considerable and protracted effort and engagement in meetings and dealings to do with land. I stress at the outset that the issues discussed in this paper are personal as they directly affect myself and my family and our futures. This paper is written from the perspective of Kaanju people living on homelands - my family and myself. We are local families and descendants of key Kaanju ancestors, therefore focal families in the claim to Batavia Downs. The views I express here in this paper are, of course, necessarily my own.
} 
- led to proceedings being dominated by claimants whose connection to the area under claim is questionable.

It also documents our serious concerns about the ability of the Native Title Act 1993 (Cwlth) (NTA) and the system of prescribed bodies corporate (PBCs) contained in the NTA to adequately and effectively recognise 'proper' on-ground indigenous governance, primary Indigenous land and resource management and decision-making on homelands, and the right of Traditional Owners to use and develop their land and associated resources economically in order to sustain their people and land into the future.

Finally it makes the point that the NTA needs to recognise that Aboriginal people should be compensated for their sovereignty being taken out of the land.

The paper will first outline briefly Kaanju governance, which determines the system of land tenure for the Kaanju people and the formation of the Chuulangun Aboriginal Corporation. This brief summary will provide the necessary framework for the discussion that follows.

\section{Kaanju Ngaachi: Kaanju Pama ${ }^{2}$}

Kaanju (Kaanichi) Ngaachi (homelands) encompass some 840000 hectares centred on the Wenlock and Pascoe Rivers in central Cape York Peninsula, Northern Australia (see Fig. 5.1). Our lands stretch westward from the Lockhart River valley and across the peninsula to and including Embley Range (meeting the Wik people and the Thanakwithi people of the west coast region). Our lands continue south to the Archer River (to meet the 'Southern' Kaanju) and north along the Wenlock as far as Schramm Creek (to meet the Atambaya and Angkamuthi people), then across to the southern bank of the upper Olive River (to meet the Wuthathi people).

\section{Kaanju governance}

Importantly, the Kaanju worldview, particularly Kaanju governance and cosmology, underlie all aspects of Kaanju relationships with homelands including land tenure and ownership, land management practices and regimes, and our rights and obligations in regard to the management of Ngaachi (see also Chuulangun Aboriginal Corporation 2005: 11-12). To Kaanju people living on homelands 'governance' refers to the system of territoriality found in the region's Aboriginal law. Our use of governance refers to the division of Kaanju country into different 'named Ngaachi' (or estates), each with their associated bloodline

\footnotetext{
2 In this paper I mainly refer to the Kaanju people associated with Kaanju traditional homelands north of the Archer River in central Cape York (sometimes referred to as 'Northern' or 'Top' Kaanju); these are not to be confused with Kaanju people associated with traditional lands south of the Archer River ('Southern' or 'Bottom' Kaanju). When I use the term Kaanju I mean only the former category of people, unless otherwise stated.
} 
or family. Thus bloodline ties people to particular country, language and resources, and to the species whose Stories lie in their Ngaachi (see Smith and Claudie 2003: 4). A number of these named Ngaachi are shown in Fig. 5.1 and include Chuulangun, Malandaji, Pa'un, Muula, Puul'u, Kathu Pathu, Nhanthanji and Iipajiko. Each estate and its associated bloodline(s) is associated with a particular Story. For example, Malandaji is the Story for 'Lightening and thunder, coming of wet season' and Chuulangun for the frilled-neck lizard (see also Chuulangun Aboriginal Corporation 2005: 12).

\section{Fig. 5.1 Kaanju homelands showing clan estates}

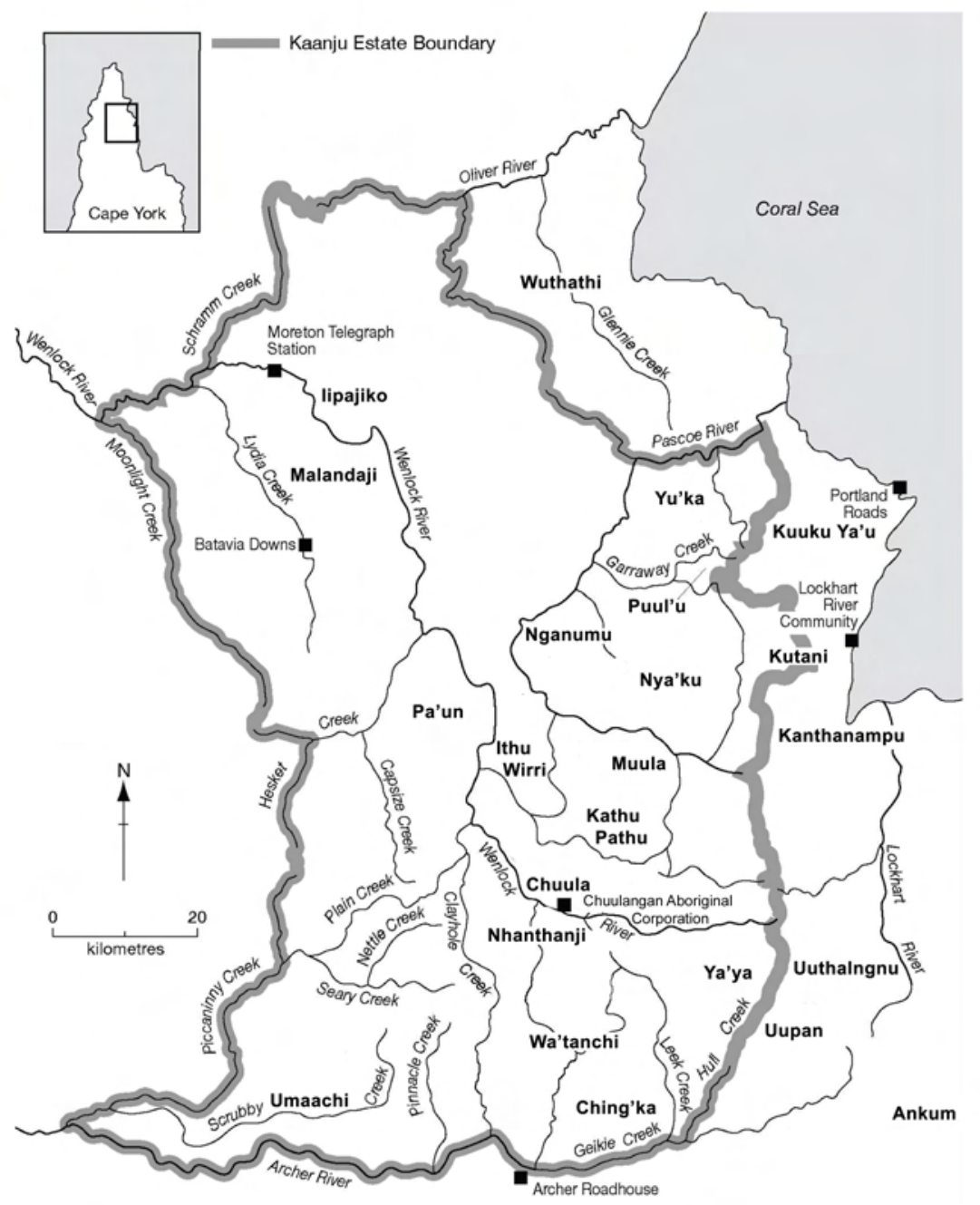


Thus particular families or bloodlines 'come from' or are connected to one or more particular clan estates. Kaanichi people determine their connection to particular country by way of their patrilineal descent from particular Kaanju ancestors. Thus according to Kaanju governance a person traces their bloodline through their father. It is understood by the majority of local families that while someone may be Kaanju due to their descent from a particular Kaanju ancestor connected to a particular clan estate, they do not necessarily have the right to 'speak for' the whole of the Kaanju homelands. Rather they have connection to a particular clan estate (or estates) within Kaanju homelands, and depending on their position (which is determined by the nature of their descent from a Kaanju ancestor and that particular ancestor's position) they may have a right to speak for that particular clan estate (or estates). At the same time it is recognised that there are particular families, and importantly, certain individuals within these families who, due to their descent from focal male Kaanju ancestors with authority, have greater authority and standing in terms of their right and obligation to speak for country and particularly to speak for the whole of Kaanju homelands. Essentially, there is a hierarchy of authority and connection to country that is determined by the nature of a person's descent and from whom they are descended. Thus a person descended from a focal male ancestor through the male line would have greater authority to speak for country and a greater area of country over which that authority is held.

Despite a significant period of disruption by colonialism, forced removals from homelands, and decades of centralisation in missions, reserves and later townships and communities, Kaanju people living at Chuulangun assert that this system of governance is as relevant today as in the pre-colonial past (see Claudie 2004). However, there are people, particularly those of the 'diaspora' living in southern cities and even people living in local communities on Cape York who operate on the assumption that this ancient system has been eroded and is no longer relevant. This dismissal of the ancient system of Kaanju governance and thereby dismissal of the authority of particular Kaanju families and individuals has enabled them to take advantage of the problems inherent in the native title process. The native title process has falsely legitimised them as traditional owners for the area under claim and legitimised what they see as their position to hold authority and make decisions in regard to the claim. ${ }^{3}$ This will be discussed in more detail later in the paper.

Today, a number of 'local' Kaanju families continue to live in centralised communities and towns including at Lockhart River, Coen, and Napranum/Weipa

\footnotetext{
3 The NTA shapes outcomes from the native title process, and the Land Council and anthropologists working on claims are bound to work within the requirements of the Act. This has lead to the inclusion, from our perspective, of the 'wrong people' in the claimant group for the Batavia Claim. People might be 'all one mob' for country in terms of a claim, but that does not mean that all native title holders necessarily have the same rights and interests as each other, even under the NTA.
} 
on the west coast of Cape York. Some Kaanju families, including those whose forebears were removed to distant locations during the previous century, live in towns including Cairns, Yarrabah, Townsville and Palm Island. A number of these latter families are recognised as 'Kaanju people' and kin by local Kaanju families, and their ancestors are recognised as being Kaanju. While they may not be necessarily living on or near their homelands they do maintain close contact with kin living in communities on Cape York (see also Smith 2006: s. 5.2.6), and they visit and attend events such as funerals. There are however a number of people, members of the 'diaspora', who claim to be Kaanju, but whose connection is disputed by local Kaanju people, particularly by those living on homelands.

In the late 1980s a number of local Kaanju families began the permanent reoccupation of homelands and re-established a home at Chuulangun (or Chuula) on the upper Wenlock River. Chuula was a main meeting place for Kaanju people before they were forcibly removed from homelands so it is appropriate that Chuula now act as the hub for Kaanju homelands development, economic development, and land and resource management on Ngaachi. The Kaanju families living at and focused on Chuulangun have undertaken considerable planning to ensure the reoccupation of homelands is sustainable and consistent with Kaanju land and resource management principles. The reestablishment of a home at Chuulangun has demonstrated the commitment of particular local Kaanju families to Ngaachi. Importantly, these families trace their descent patrilineally through the male line from key Kaanju ancestors. In the case of the Moreton/Claudie/Nelson family of which I am a member, our key ancestor is recognised among a significant number of Kaanju people living on or near homelands and by Aboriginal people more widely as having been an important law man and holding important knowledge to do with the land, governance and cosmology. He is recognised as a key Kaanju ancestral figure (see also Smith and Claudie 2003: 6).

\section{Chuulangun Aboriginal Corporation}

In July 2002 our family-based community living at Chuulangun incorporated under the Aboriginal Councils and Associations Act 1976 (Cwlth). Our organisation is localised and based on Kaanju governance structures. As for the Murray Lower Darling Rivers Indigenous Nations (MLDRIN) (Weir and Ross, Chapter 10), the Chuulangun Aboriginal Corporation is a modern-day extension of traditional governance structures. Our organisation's founding principle is:

a person must live on their particular homeland in order to have a say in its management.

The main objectives of our organisation include: 
- representing the Kaanju people associated with the Wenlock and Pascoe Rivers on land tenure, land and resource management, economic and homelands development issues;

- facilitating the practice and maintenance of the customary obligations of Kaanju people in regard to land and resource management for homelands;

- promoting the wider recognition and support, particularly by government, of primary Kaanju management and decision-making for our homelands;

- facilitating the reestablishment of permanent Kaanju communities on our homelands;

- establishing homelands-based economic enterprises that will sustain or people and our homelands into the future; and

- having greater access and control over the resources and funds available to help meet the above objectives.

Foremost, our incorporation was fuelled by our frustration at the inability of regional and sub-regional Aboriginal bodies (particularly our Native Title Representative Body) to help us meet our land and resource management, homelands development and economic development aspirations (see also Smith and Claudie 2003: 7-8). Incorporation was seen as a strategy for the wider recognition of Kaanju governance and assertion of the primacy of Indigenous land tenure and our authority as landowners and land and resource managers.

Chuulangun Aboriginal Corporation is undertaking a number of land and resource management, homelands and economic development activities on Ngaachi. Recently, focal Kaanju Traditional Owners living at Chuulangun (and native title claimants to Batavia Downs) have been investigating the establishment of an Indigenous Protected Area (IPA) over some 470000 hectares of our homelands centred on the Wenlock and Pascoe Rivers. This area includes the Kaanju portion of the Batavia claim. Our aspiration is that the area be declared as an IPA and that it be managed in accordance with the International Union for the Conservation of Nature and Natural Resources' Protected Area Category V: 'Area of land and/or seascape protected mainly for conservation/recreation purposes'. It is not our intention to use the land for pastoral purposes as we are not pastoralists, and this land use would work against our conservation purposes for the land. It is however our intention to benefit from the land economically, mainly by way of the management of public use and access (e.g. establishment of designated campgrounds and low-key tourism), and other natural resource management based activities (e.g. feral animal control, sustainable use of plant products). These activities would generate opportunities for employment and training for our people on homelands as well as provide revenue to support the 
permanent reoccupation of homelands and help sustain viable homelands communities. $^{4}$

\section{Background to the claim}

Malandaji is an important Kaanju Story Place on the upper Wenlock River. It has particular significance as the Story for 'Lightening, Thunder and the Coming of the Wet Season'. For a number of decades core Kaanju people associated with the area of Malandaji and living at Chuulangun have been concerned about prolific and unregulated public access to the area, which has resulted in damage to this significant site. We are concerned that abuse of the area will get in the way of the ability of Malandaji to carry out its role in the Kaanju cosmology. There is also concern that people who abuse the area and who are there without the authority of Traditional Owners will suffer severe consequences under Kaanju law and custom.

Malandaji, and some 635000 hectares of the (Northern) Kaanju Homelands, ${ }^{5}$ have been alienated from Traditional Owners by the imposition of a number of government land tenures including pastoral lease, National Park and timber reserve. Malandaji was imposed upon by the Batavia Downs Pastoral Holding, a former Experimental Farm Reserve now managed by the Queensland Department of Natural Resources and Mines (DNRM), and locally known as Batavia Downs. Our particular concern for Malandaji as well as our aspirations to regain control and management of our traditional homelands drove our claim to Batavia Downs.

In October 1997 a native title claim (Northern Kaanju People \& Yianh People QC97/45) ${ }^{6}$ was lodged to some 241000 hectares of our homelands along the Wenlock River, an area that includes the former Batavia Downs Holding and Moreton Telegraph Station. Specifically, the area of the application includes the area known as PH 43-5371, Experimental Farm. Lot 2 Crown Plan DLH5, including an area previously known as Batavia Downs Pastoral Holding. The claim has become known as the 'Batavia Claim'. Due to amendments to the NTA the claim had to be relodged with the National Native Title Tribunal (NNTT) so it did not really get going until 2000. Under Kaanju law and custom, the Kaanju people living at Chuulangun as well as a number of families living at Coen, Weipa/Napranum, Lockhart River and at more distant locations are the particular Kaanju people from the particular area under claim.

\footnotetext{
4 For more information on the Chuulangun Aboriginal Corporation and its activities visit $<$ www.kaanjungaachi.com.au $>$.

5 A further 204150 hectares of the Northern Kaanju Homelands fall within the boundary of the former Lockhart Deed of Grant in Trust (DOGIT) that was transferred as inalienable Aboriginal Freehold under the Aboriginal Land Act 1991 (Qld) to traditional owners as part of the Mangkuma Land Trust.

6 In this paper I am speaking only for our Kaanju Homelands in the claim area, not also for the Yianh territory in the claim area.
} 
The Government-appointed Native Title Representative Body for our claim is the Cape York Land Council (CYLC). Our claim is currently subject to negotiations towards an Indigenous Land Use Agreement (ILUA) with the Department of Natural Resources and Water the peak State government body for land tenure and management negotiations (formerly the Department of Natural Resources and Mines (DNRM)). Moreton Telegraph Station is currently subject to annual lease arrangements as a camping ground with Cook Shire as trustee.

\section{The native title process}

Kaanju traditional owners living at Chuulangun recognise three main impediments to the claim: the State, the Native Title Representative Body, and the nature of the claimant group and its representation. The native title process itself has been at the heart of and/or exacerbated these problems. The nature of the native title process is such that it has enabled our claim to be dragged out for eight long years while (1) the State takes its time to come to an agreement with us on land tenure, land use and management arrangements, (2) our Native Title Representative Body pauses then attempts to organise itself, and (3) claimants whose actual connection to the claim area is questionable continue to dominate proceedings to the detriment and exclusion of Kaanju families actually from the area under claim.

\section{Native title and State land dealings}

During 2001 the registered native title claimants were approached to prepare a negotiating position relevant to the tenure resolution of Batavia under the framework of the State Lands Dealing Project. We spent considerable time, money and energy, meeting and synthesising three years worth of planning material compiled by planners, environmental scientists, anthropologists, and other professionals who have worked with the Kaanju people. The resulting report, the Batavia Downs Aspirations Planning Report (BDAPR) (Kaanju People and Salmon 2000) set out in detail our plans and aspirations for the management of our homelands under claim. This report is based on Kaanju Indigenous governance and land and resource management principles and practices that have been passed down over many thousands of years through Kaanju bloodlines to the current generation of Kaanju land owners, land managers and law makers living on country. It also addresses major land management problems not of our making, including weed and feral animal infestation and the destruction of sensitive ecological areas and desecration of important cultural sites due to prolific and unregulated public access to and use of our homelands.

In September 2001 we presented our report to the State government. While the report suggested an extremely high probability for a successful tenure resolution, which would satisfy the needs of all stakeholders, we never received a response from the State. Instead, 12 months later in September 2002, when we were under 
the impression that our claim might be close to resolution, the State, under the guise of the State Land Dealings branch of the DNRM, announced that they had to produce a 'Land Evaluation' report on the claim area, a process that would take up to 18 months. The native title process was essentially captured by DNRM's 'Land Evaluation processes' ${ }^{7}$ Up until that point we had the impression that we had been dealing in good faith with a State framework aimed at the rapid resolution of a long-standing land issue of critical importance to us. However, with no formal notification or explanation regarding a change of process we were left guessing about the status of our land and the State government's intention in relation to it. We had no clear picture of departmental responsibility for an expedited dealing on Batavia. There was even some confusion amongst government officers as to the status of our dealings on Batavia. It was even suggested to us that Batavia was no longer 'on the table' for dealing'. ${ }^{8}$ The sentiment of one senior Traditional Owner when the CYLC advised that claimants should question the State about the bureaucratic hold-up over Batavia was: 'I don't want to keep talking and wasting my voice. ${ }^{\prime 9}$

Indeed, the land tenure history of Batavia Downs has been uncertain from the start. The whole area has been a pastoral lease at some stage so according to government, native title to most of the country has been extinguished due to previous interests. However, the CYLC advised claimants at a Steering Committee meeting held in September 2003 that the State was uncertain about extinguishment of native title on Batavia. We were advised that native title determination was still of value particularly as there were no current leaseholders. ${ }^{10}$ We were further advised that based on the extinguishment of native title scenario if the claim went to court the best determination we could expect over Batavia Downs would be non-exclusive determination of native title. However, Aboriginal Freehold under the Aboriginal Land Act (ALA) was seen as a lot more valuable than non-exclusive native title, so we pursued the former option. Nevertheless, there was still (and still is) the question of whether native title has really been extinguished over the area.

We waited for the State's Land Use Evaluation Report. When we expected that the report would be finished we spent considerable time and energy making numerous inquiries to DNRM about the report. Our repeated requests to view the Land Evaluation report were ignored. Although at a National Native Title Tribunal Mediation Conference held in Cairns on 24 July 2003, the State's

\footnotetext{
${ }^{7}$ Letter to the Minister Hon. Steve Bredhauer RE: HoAIG Meeting held 20 September 2002 from Gerhardt Pearson, Executive Director, Balkanu Cape York Development Corporation, dated 24 September 2002.

8 Letter to the Minister Hon. Steve Bredhauer re Batavia Downs (Formerly the Batavia Experimental Farm Reserve) Cape York, from David Claudie, dated 20 September 2002.

9 M. Sellars, at Batavia Downs Steering Committee Meeting, Cairns, Friday 18 January 2002, CYLC minutes from meeting, p. 6.

${ }^{10}$ K. O'Rourke, at Batavia Steering Committee Meeting, CYLC Conference Room, Monday 1 September 2003, minutes from meeting, p. 1 .
} 
representative did state that he would seek Ministerial approval to release the report to parties to assist with the process of tenure resolution over Batavia Downs. ${ }^{11}$ However this was to no avail. Finally, in late 2003 through our contacts within an Australian conservation organisation which accessed the report through Freedom of Information legislation we were finally able to access this report, albeit a very poor quality facsimiled copy. To date, the DNRM has not provided Kaanju Traditional Owners living at Chuulangun with a copy of this report.

My initial impression of the report was that it was merely a 'desktop study' and a very poor one considering the amount of time it took to produce it. The authors undertook a 'site inspection' over only four days, holding meetings with caretakers at Batavia and Moreton, and Bramwell Station (not even in the claim area). No attempt was made to meet with Kaanju people on homelands. The authors make assumptions and generalisations about the land and associated resources that indicate a very poor understanding of the area under claim. They also do not seem to have read very carefully the claimants' submission (BDAPR). My comments are centred on a number of issues as discussed below. ${ }^{12}$

\section{Batavia Downs and cattle enterprise}

Overall, the report makes a lot of assumptions and simplifies considerably and to our disadvantage, Kaanju people's aspirations with regard to the area under claim. For example, it notes that the Traditional Owners 'have a strong interest in seeing Batavia Downs return to a viable cattle enterprise'. This is completely false, and the Batavia Downs Planning Report (the submission we sent to DNRM for the purpose of informing the State of our aspirations) does not say this at all. The only mention our report makes about cattle is the need for management of land degradation caused by cattle and the maintenance of a 'killer' herd for local use. The assumption that Kaanju people want to run a viable cattle enterprise, along with the very strong support for pastoralism on Cape York (e.g. submissions from Agforce, Peninsula Cattleman's Association, Cape York Live Export Group, Cook Shire, Cape York Peninsula Development Association, as well as some pastoralists) only supports the State's plans for pastoralism in the region and

\footnotetext{
11 J. Bednarek, at National Native Title Tribunal Mediation Conference, Meeting Summary, Native Title Determination Application QC97/44, Summary of Outcomes, 24 July 2003, p. 3.

12 I have not attempted to discuss the views of those who wrote the Land Evaluation Report for a number of reasons (1) because I do not agree with these views, (2) because I do not understand how the authors of that Report came to their conclusions or how they justify them (not least because they did not consult with the Traditional Owners in reaching them), and (3) because including those views here would grant them a degree of legitimacy I do not consider appropriate. The views I express here are, of course, necessarily my own. It is important to note a possible difference here between the norms of academic practice - a (supposedly) 'objective' encapsulation of various viewpoints - and the ways many Indigenous people speak on similar issues. As suggested by Smith (2005: 9) the presumption of an 'objective overview' involves an idea that the commentator can view a situation 'from outer space'. Many Aboriginal people would view this as either impossible or meaningless. I can only speak from what I know is right from my own Indigenous governance, with my feet planted solidly on my homelands.
} 
justifies (from their point of view) their discussion on and recommendations that the majority of the holding be pastoral.

For Batavia to return to a viable cattle enterprise would involve considerable financial resources, which would be provided by whom - the State? The report does mention the considerable distance of Batavia from markets and the poor nutritive value of native vegetation (Sinclair 2003), which are only two factors against pastoralism (there are many more), but it does not consider these when recommending that the majority of the holding return to pastoral use. This recommendation they base on the findings of only one document, which was produced by the Department of Primary Industries. Further, Aboriginal people do not 'belong to cattle'; it is an industry that was forced upon us. There is a widespread assumption that because a few of our old people were 'cattlemen', all Aboriginal people want to do with the land is run cattle. This is completely false.

The State's Land Evaluation Report seriously misinterprets and misrepresents core Traditional Owner aspirations with regard to the claim area. It is not our intention to return Batavia to a viable cattle enterprise. We intend to resume our customary management of this area, which is our obligation under Kaanju law. This management will involve, amongst other considerations, repairing the considerable damage caused by the cattle industry, as well as by the prolific access and use of our homelands by third parties, and weed and feral animal infestation, as part of the framework of the IPA.

\section{Moreton Telegraph Station}

The report also recommends that Moreton Telegraph Station remain under the management of Cook Shire. There is absolutely no consideration of the Kaanju people's aspirations with regard to the area (again detailed in our submission to the State). Our position in the case of Moreton is ignored or seen as irrelevant. Cook Shire's stake in the area of Moreton Telegraph Station is seen as more important than that of the Traditional Owners.

\section{Conservation values}

The report does not acknowledge that Indigenous rights and obligations with regard to land and resources extend beyond cultural considerations. The State's assumption is that our management is only relevant in the case of significant cultural sites, in this case Malandaji or what they call 'Wenlock Falls'. In the Report the State recommends transferring the area around the 'Wenlock Falls' to traditional owners under the ALA. Perhaps they think that this will satisfy our obligations to 'look after' our country. 
Further, the State sees 'nature' conservation and sustainability as the domain of conservation groups and government themselves. ${ }^{13}$ They recommend that any land transferred to Traditional Owners or taken up by Traditional Owners as pastoral lease be subject to conservation arrangements and restrictions on tree clearing. Under customary law, Kaanju people do not clear trees, and today we would only clear land if it was absolutely necessary for our homelands development, say for an airstrip for access to essential services. But even before clearing trees for an airstrip there is a process of customary obligations to be undertaken in order for that activity to be sanctioned under Kaanju law. Again the State assumes that Indigenous people cannot manage the land in a sustainable manner and that our land use and management regimes have no legitimacy in contemporary society. This equates with the view of some of the diaspora and even local Kaanju people who are of the opinion that traditional Kaanju governance should belong to the past.

The State needs to recognise that Kaanju people's obligations with regard to the management of our traditional lands and associated resources encompasses more than merely cultural aspects. Our BDAPR report outlines in detail the background and key principles of Traditional Owner land use and management responsibilities for Batavia. It states, 'the natural and cultural values of ... [Batavia] cannot be separated'. Further, 'how people want to use and manage land is often informed by their particular responsibility to and for places, as well as a responsibility to generally manage country responsibly' (BDAPR 2000:30).

After several years of guessing about the status of our land and the State government's intention in relation to it, the State finally put their position to us at the 24 July 2003 mediation. The State's position at the time of this meeting was that the acquisition of the former pastoral lease and also the Moreton Telegraph station had extinguished native title (being most of the claim), and that it would like to settle the claim in the following ways:

- a pastoral lease for native title holders of the area to the west of the Wenlock River;

- the area east of the Wenlock River to be ALA Freehold grant, and

- the northern part to be part pastoral lease and part National Park (the reason for this was so the government could do a deal for National Park around the Olive River Area).

13 Chuulangun Aboriginal Corporation have recently entered into a Cooperation Agreement with an Australian conservation organisation with the aim to further core Kaanju Traditional Owner rights and interests in regard to our Ngaachi and to support our native title and land and resource management aspirations. Importantly, this agreement has been initiated by core Kaanju families living on homelands who are recognised by this conservation group as the core Traditional Owners for the Wenlock and Pascoe Rivers. To view the agreement visit < http://www.indig-enviro.asn.au/\#kaanju>. 
Further, the State wanted a conservation agreement to be made over certain areas and a common management regime over the rest of the area. ${ }^{14}$

It is my impression that the State had already made their decision on where they wanted Batavia to go and that the 'land evaluation process' and preparation of the Land Use Report was just a way of formally getting the support needed to justify the position they put to us at the 24 July 2003 mediation meeting. Further, there appear to have been only three players in this whole process: the government, the pastoral lobby and the conservation groups. Core Kaanju Traditional Owners have been pushed aside in this process and our case as major stakeholders and legitimate owners and managers of the land and associated resources has not been recognised from the start of the process. As Traditional Owners of the land under question, we are infuriated at the State's arrogance in presuming that our homelands are theirs to make deals over. Aboriginal people are repeatedly being asked to prove land ownership to government; what about government proving that they own the land? ${ }^{15}$

The CYLC outlined our two options regarding our claim at a Steering Committee meeting held on 1-2 September 2003:

- progress Native Title, the possible outcomes being a) non-exclusive determination of native title, b) no native title outcome and further mediation; or

- $\quad$ propose a deal with the State (as above).

The Native Title Claimants Proposal for Tenure Resolution over Batavia Downs was submitted to the then Minister for Natural Resource and Mines, Stephen Robertson, on 3 September 2003. We confirmed our desire for the State to move to a speedy resolution of tenure issues on Batavia and stated that we were prepared to negotiate an outcome with the State based on the following:

- that the area to the far north west of the claim area be set aside for a National Park;

- that the majority of the area be transferred to Traditional Owners as Aboriginal Freehold with conservation agreements over identified areas; and

\footnotetext{
14 National Native Title Tribunal, Mediation Conference, Meeting Summary Native Title Determination Application QC97/44, Summary of Outcomes, 24 July 2003.

15 Muir (1998: 4) notes that the 'approach to native title should reflect the fact that the Mabo decision recognised a system of laws, Indigenous laws, and that those laws allocated rights in land, albeit subject to the Crown's right of extinguishment. Where extinguishment did not occur then as a matter of logic native title or rights to land allocated through Indigenous laws must continue to exist'. In other words, where government cannot prove that they own the land through extinguishment, Traditional Owners for those particular tracts of land should not have to prove their ownership, as it still exists.
} 
- that an area on the north west portion of the claim area be leased for pastoral purposes and that any such a pastoral lease be made available to Traditional Owners. $^{16}$

Our overall position was that if it is the case that native title had been extinguished over much of the area, these areas should become Aboriginal Freehold under the ALA. From there conservation agreements and land management arrangements may be negotiated, with the bottom line being primary Kaanju management and decision-making regarding the land and associated resources. Further, our proposal to establish an IPA over the claim area would satisfy the State's proposal for conservation agreements over much of the claim area.

\section{Cape York Land Council}

Throughout almost the entire period of the claim the role of our Native Title Representative Body, CYLC, has been problematic. For example, during the whole process of the dealings with the State it was not able to access the State's report on Batavia Downs (or if it did access the report it did not make it known to the Traditional Owners). Numerous requests made by the author of this paper to the lawyer heading the claim that CYLC obtain a copy were all but ignored, or at least from our perspective it seemed they made little effort to obtain a copy. Throughout the whole process of the dealings with the State as described above the CYLC appears to have been taking a minor role, waiting for the government to call the cards rather than acting in the interests of the people they are supposed to represent.

In June 2004 the CYLC contacted native title claimants for the Batavia Claim explaining why they had not heard from the Land Council in such a long time and also to provide an update on what had been happening with the Batavia claim. ${ }^{17}$ The letter explained that there had been a large turnover in staff and they were making a number of changes as action on decisions made by the Executive Council. ${ }^{18}$ One of those changes was to develop a native title claims policy. In their words:

This policy provides a way to manage the work of the Land Council. It is simply not possible for us to deal properly with more than two dozen claims, as we have at the moment. Everyone involved in native title and land work understands that we need to work out which matters need to

\footnotetext{
16 CYLC, Letter to Stephen Robertson Minister of Queensland Department of Natural Resources and Mines from Traditional Owners of Batavia Downs. 2 September 2003.

17 J. Brooks, Letter to Native Title applicants Northern Kaanju and Yianh People (Batavia) from the Cape York Land Council, 10 June 2004.

18 It should be noted that during the history of the Batavia Claim there have been at least four changes in the Land Council lawyers heading the claim.
} 
be given more attention now, so that all traditional owners groups across the Cape benefit in the long run. ${ }^{19}$

It was decided that the most complex matters-Wik and Eastern Kuku Yalanji - needed to be completed as soon as possible so that staff and resources could be freed up for pushing other claims along in the future. It was noted that finalising those claims should pave the way for sorting out other applications, 'for everyones' benefit'. They asserted, 'Based on that policy, we need to prioritise our work on applications and put the necessary resources against the matters which have the highest priority' (Brooks 2004).

The Land Council hence put Batavia on the back burner while they concentrated on more complex claims. Only recently have the Land Council contacted claimants about Batavia. This has come at the same time as negotiations over a proposed gas pipeline that will pass through Cape York Peninsula. ${ }^{20}$

\section{The claimant group}

As discussed earlier, under the Kaanju land tenure system particular families or clans are particularly associated with or 'come from' particular tracts of land or clan estates within the overall umbrella of the Kaanju homelands. Further, based on hierarchy particular individuals within these families have authority to speak for the land, while others do not. What this means is that not all people who identify as Kaanju come from the entire (Northern) Kaanju homelands. However, the native title process is such that, although the claim is only to part of the Kaanju homelands north of the Archer River and therefore covers only particular clan estates, people who identify as being Kaanju people from north of the Archer River are listed as claimants. This presents a number of questions for the core Kaanju families who are actually from the area under claim. How can people who are not even from the area under claim be listed as claimants on the native title claim? How is it that a number of these people speak for the land under claim at mediation and steering committee meetings when they have no right to do so under Kaanju law and custom? Further, in formal discussions and negotiations regarding development proposals concerning the area under claim, these people also speak for the country, as has been the case with negotiations over the gas pipeline.

What this translates to is that there are claimants on our claim who are not from the area under claim, and therefore people speaking for our land when they have no right to do so under Kaanju law and custom. This has been particularly

19 J. Brooks (ibid.).

20 The Cape York Land Council signed an agreement with the original proponents for this gas pipeline back in 1997. The proposal involves a 2500 kilometre pipeline to transport natural gas from the Papua New Guinea highlands, across Torres Strait, through Cape York, northern and central Queensland, to Townsville and Gladstone. The proposed route for the gas pipeline travels through some 60 kilometres of Kaanju homelands, some 45 kilometres of which is in the Batavia claim area. 
evident at a number of the mediation meetings at which I have been present, where claimants who actually live on country have been obstructed in having a say by Tribunal staff who have given preference to claimants who do not live on the peninsula, who are not from the particular area under claim, and indeed whose claims to being Kaanju people, according to Kaanju people living on homelands, are questionable. ${ }^{21}$ It is the inadequacy of the claims process that has allowed this to happen. 'The land does not belong to them' is the sentiment of the focal Kaanju people from the claim area.

Our understanding is that when the claim was first lodged with the National Native Title Tribunal it was rejected, due not only to amendments to the NTA, but also to there being a small claimant group. This original claimant group was a more accurate indication of the Kaanju people connected to the area under claim than the present claimant group that is made up of people who identify as Kaanju north of the Archer River, but not necessarily as Kaanju belonging to the actual area under claim. To reiterate, a number of the claimant families may identify as Kaanju, but they do not come from the actual area under claim. Herein lies another of the failings of the native title process, being that it does not recognise that Indigenous land tenure systems are very localised. The native title process, particularly the Native Title Representative Body in that process, takes a regional and sub-regional approach to land tenure systems that is inappropriate and non-Indigenous and thus inherently problematic and goes against the proper recognition of native (Indigenous) title and governance. As noted by Bauman and Williams, 'broadly defined regional native title systems can overlook specific localised and individualised rights and interests as representatives of the broader group are seen to have an equal say in making decisions about matters which may not be their primary concern' (2004: 11).

The Batavia Native Title Application identified the claimant group in the following terms: ${ }^{22}$

The Northern Kaanju claimants identify themselves, and are identified by the other Aboriginal people of the Central Cape York Peninsula region, as the group of people whose native title rights and interests under Aboriginal law and custom, are to that area of land associated with the Kaanju language which lies north of the Archer River and extends north to the area of the Moreton Telegraph Station. (CYLC 1999: 1).

\footnotetext{
21 I have been present at a number of Mediation meetings during the eight year long history of the claim. I recall in detail the events of one particular meeting where my Aunty (who has since passed away) began to talk about claim and raise an important issue but was rudely interrupted by Tribunal staff who gave preference to diaspora claimants who wanted to have their say. Despite attempts my Aunty was not given the opportunity to speak up later in the meeting. I noted that my Aunty's attempts to speak were not noted in the official minutes of the meeting.

22 As noted above this paper concerns the Northen Kaanju people and Northern Kaanju portion of the Batavia claim, and not also the Yianh people and Yianh portion of the claim area.
} 
The application outlines current membership of the group as being primarily through the principle of cognatic descent, that is, descent traced through both male and female ancestors. Further, members traced their descent from a limited set of persons recognised in the regional Aboriginal community as having been Kaanju occupants of the claim area (CYLC 1999: 1). Thus the current membership of the Northern Kaanju peoples, according to the application, comprises a number of cognatic descent groups or families who are identified by their main surnames together with the apical ancestors from whom they trace their descent cognatically (CYLC 1999:1). The application lists 21 Northern Kaanju families and their apical ancestors. Notably, the 'descendants of George Moreton Snr and his wife Mary Ann (both deceased), being members of the Moreton/Nelson Family' is the first listed cognatic descent group. However, the application does not indicate that not all the Kaanju families listed are from the actual area under claim, nor does it indicate that particular families and individuals within those families have the right to speak for particular tracts of land within the claim area, while others do not. It has been a 'boxed up' claim from the start which today is not necessarily the perspective of core Kaanju families living at Chuulangun for that area of their homelands.

This approach to the formation of the claimant group is supported in the draft Connection Report. As Smith notes:

... it is my conclusion with regard to the Batavia Downs native title claim that the proper 'social scale' at which the claim be determined is that of the 'macro-grouping' of one or more (in this case, three) contemporary language-named or place-based 'tribal' groups (despite the fact that a number of claimants might not regard this as the most significant social scale at which customary interests are articulated among the indigenous people of the region). This conclusion is based on native title case law and the contemporary and continuing forms of local custom and law pertaining to the claim area, both of which lead me to conclude that this is the most proper way in which the native title holding group for the Batavia Downs area can be recognised (2006: 8, 10, emphasis in original).

At the same time in the draft Connection Report Smith acknowledges the importance of the principle of patrilineal descent to a number of Kaanju families:

[A]n emphasis remains among many members of the 'home population, on the 'proper' principle of patrifilial recruitment or 'patrilineal descent' ... whilst Northern Kaanju people recognise both descendants of Northern Kaanju men and women as Northern people, and as 'proper' Northern Kaanju claimants in Native Title claims ... there remain vestiges of the greater weight placed on patrifilial recruitment ... this remains a matter for decision and negotiation between and within Northern Kaanju families rather than a hard and fast rule (2006: s. 5.2.6). 
Smith (in an earlier version of Chapter 6) notes the difficulties apparent in 'reified codifications of such groups that anthropologists, lawyers and others inevitably create in the production of "connection reports", prescribed bodies corporate and other statements of the relationship between Aboriginal people and their "traditional land".' Claimant groups are seen as 'categorically defined, bounded and non-negotiable' (Bauman and Williams 2004: 11). The problem with such groups is that what is presented on paper does not necessarily reflect what exists in reality on the ground where the action is taking place in terms of land management and Traditional Owners living and working on country. From our perspective as Traditional Owners living on homelands the claimant group is an artificial group, but has become legitimised by the native title process. Bauman and Williams (2004: 11) note that the 'need to define groups categorically does not account for differentiation within and across groups', which 'creates fertile climate for disputes concerning who has the greater claim or authority over the country and the appropriate grouping to which native title should be attributed.'

Foley (Chapter 7) alludes to the 'usurpers' who, through the power structures of specific land councils, are given legitimacy under New South Wales statute law and become custodians in European terms over issues of native title. Similarly for the Batavia claim, a number of claimants have had their position as Kaanju people, and in the case of named applicants on the claim, as people who hold authority to speak for the land under claim, legitimised by the native title process. Thus while under government law their identity as Kaanju people and authoritative people to speak for land is recognised, under proper Indigenous law they are not recognised. This situation of being recognised under government law but not under Indigenous law further fuels the view of local people that these claimants see government law as superior to Indigenous governance. This is reinforced by the NTA itself. As noted by Muir, "the "determination process" established by the NTA takes us full circle to a situation that again supports the notion that the Australian law is the only legitimate law' (1998: 3).

As noted by Smith what comes across as problematic in land claims is the marked difference between how local people and diaspora people assert connections to country. 'Diaspora people often reject a distinction between their connection and those of local families, asserting that, regardless of location, they hold equal interests in (and connection to) the country of their forebears' ((2000: 2; see also Smith 2000: 4). However, in the case of Batavia Downs who their actual forebears are is also questioned by local people.

While for a significant number of local people ancient or 'classical' forms of governance and associated kinship and territoriality remain, for diaspora people, the shift towards a tribal identity has been far greater (see also Smith 2000: 4). Within such a model, 'diaspora people tend to presume that each tribe holds 
homogenous rights over a "tribal area" of language-associated country' (Smith 2000: 6).

Again as noted by Smith in the draft Connection Report:

Given the existence among Northern Kaanju people of a widespread assertion of customary connections to the broader Northern Kaanju homelands area, and the requirement under Native Title law to recognise such wider connection, rather than delimiting the membership of claim groups to those asserting a particular or primary connection to a claim area within such broader assertions of connection, the description of the Northern Kaanju group for the purposes of this (and other) claims necessarily includes the wider set of 'Northern Kaanju' families (2006: 10).

This situation is made worse by the philosophy that can be summarised as: 'get your land back first and then sort through internal issues after that'. One of the justifications for this idea is that it is not the business of the government where the Aboriginal boundaries are within the claim area, only where the external property (government) land boundaries are. However, this creates problems for legitimate Traditional Owners (that is, the focal claimants) who have to 'pick up the pieces' and dismantle the obstacle of the imposed government-sanctioned prescribed body corporate $(\mathrm{PBC})$ or land trust in order for the unobstructed carrying out of land management rights and obligations.

\section{The prescribed body corporate}

Under the NTA an incorporated native-title body, a PBC, is required to hold the native title rights and interests that form the 'title' once the claim is determined, or in the case of the Batavia Claim an ILUA is established (once tenure arrangements issues are resolved). Like other corporations the PBC (or land trust) requires a constitution outlining the rules and objectives by which the corporation will function. We anticipate problems when at the determination of the claim or tenure resolution a PBC or land trust is formed that includes all members of the current claimant group. How will a constitution be drawn up and how will the constitution, if at all, address issues concerning management and decision-making of the land? And particularly how will it deal with the issues of which members of the group hold the authority to speak for country? We anticipate serious problems in this regard.

It is useful here to refer to Glaskin's contribution to this volume (Chapter 3). Glaskin focuses on the discussions concerning the development of a PBC for the Bardi and Jawi native title claim in the north-west Kimberley region of Western Australia. She notes that as claimants discussed the constitution for their PBC, one aspect that they felt had to be incorporated within the rules concerned the role of the madja-madjin ('Law bosses' or senior ritual experts) within their 
society. While it might be useful to incorporate such a consideration in the constitution for the $\mathrm{PBC}$ or land trust for the Batavia claim determination, the problem of differing opinions on who are the proper people who hold authority will inevitably be hotly debated as the situation is now. Glaskin (Chapter 3) notes that from the view of the claimants the formation of the PBC was closely linked with the development of a particular kind of constitution that adequately upheld Bardi and Jawi 'Law, language and culture'. Glaskin cites Sullivan's (1997: 139) description in relation to the Rubibi constitution as being 'nothing less than an attempt at a self-governing structure reflecting customary Aboriginal law'. But what happens when different claimants have differing views on what that is, as is the case for the Batavia claim?

Again as Glaskin describes in Chapter 3, another group of claimants maintained a position that principles of land ownership (recognising specific interests in country, with reference to estates) should be made clear in the constitution for the PBC. Such a principle would be of considerable importance in the drawing up of the constitution for the native title holding body for the Batavia claim based on the current claimant group. However, the drawing up of a constitution that considers the existence of specific interests in country and the association of particular families with particular estates has been slowed down by decisions made at a March 2006 meeting organised by the CYLC. Agenda items for this meeting included the identification of 'all the Kaanichi Kaanju Elders' and confirmation of 'traditional laws and customs of the Kaanichi Kaanju People in relation to their tribal lands and decision-making processes'. Notwithstanding the seriously questionable process by which the meeting was organised and the process and context of the actual meeting itself, at the meeting, after the 'Elders' were identified, one of the decisions made by the Elders was that 'there are no special sub groups rights' in the consultation or decision making processes for the Kaanichi Kaanju People. ${ }^{23}$

\section{Indigenous land management, sovereignty and compensation issues}

We have concerns about the ability of native title to recognise that our sovereignty has been taken out of the land by the colonisation process and successive series of government policies and practices past and present, that saw

\footnotetext{
23 The Kaanichi Kaanju Elders, in a letter addressed to David Claudie, 2 March 2006. Two weeks' notice was given for this meeting and it was held in Cairns, some 1000 kilometres from Kaanju Homelands, during the wet season. A number of people were unable to attend who should have, including myself. If native title is about recognising traditional law and custom the Land Council should be recognising Elders under traditional law and custom, and not by way of a meeting organised by them to identify Elders under non-Indigenous Land Council processes and the native title process. As for the claimant group for the Batavia claim, the processes of the Cape York Land Council and the native title process itself have given 'all the Kaanichi Kaanju Elders' legitimacy as the authority for the land. This is very problematic.
} 
Kaanju people forcibly removed from homelands and centralised in towns and government orchestrated communities. When we were taken out of our land, the sustainable management of the land and associated resources were severely disrupted. Associated with taking the sovereignty out of the land is the prevailing assumption that the land is 'empty' and Indigenous land and resource management is no longer effectual, no longer exists or is not relevant in today's 'modern' society.

However, Kaanju land and resource management does exist and permanent Kaanju communities are being re-established on our homelands, including in the area subject to the Batavia claim. Focal Kaanju Traditional Owners have developed a comprehensive Land and Resource Management Framework and an IPA Management Plan that sets out in detail the management of our lands and associated resources. Like our BDAPR report these documents are based on Kaanju governance and land and resource management principles and practices that have been passed down over many thousands of years through Kaanju bloodlines to the current generation of Kaanju land managers and law makers living on homelands.

When we were forcibly absent from our homelands other management regimes had taken over (namely by government) in the form of pastoral and mining leases, National Parks and forest reserves. Due to the inappropriateness of these regimes we now face a myriad of land management problems not of our own making, including weed and feral animal infestation, land degradation, the destruction of important ecological environments, and the desecration of cultural sites by prolific and unregulated public access.

What the NTA needs to recognise and enforce is that our sovereignty is still in the land and that Traditional Owners need to be compensated, in the form of funding and resources, in order to carry out obligations as primary land managers and decision-makers and return the land to its sustainable state. This includes support for homelands and economic development. However, what will need to be reinforced is that any funding and resources that are forthcoming would have to be spent on country. During recent negotiations over the proposed gas pipeline the issue of compensation or royalties was discussed. From the perspective of Kaanju people living on homelands any royalties from the gas pipeline would have to go into a trust or incorporated body as described above and be spent on country for the benefit of the land through which the pipeline passes, for example, on land management projects such as weed and feral animal control, biodiversity conservation and fire management. The way that Kaanju people would benefit financially would include being actively engaged in these projects on homelands and be paid wages for their work.

Further, the legal system does not recognise commercial rights under the NTA, only traditional rights, therefore we often have to negotiate with government 
and other stakeholders to make agreements in order to get what we want. Apparently, 'Native Title is about rights and interests not ownership' ${ }^{24}$ and as such does very little to accommodate Traditional Owner plans for homelands and economic development, and aspirations for the improvement of our health, social, spiritual, and economic well-being. ${ }^{25}$

\section{Conclusion}

The dealings with the State regarding tenure resolution and management arrangements over the area of Batavia were cause for considerable concern in the period from about 2001 to 2004. From our perspective the State was (and still is) taking its time on the issue and playing bureaucratic games over our traditional homelands. But while our own and the efforts of our Native Title Representative Body were engaged with this issue, dispute about who has the right to speak for country and questions about the nature of the claimant group itself were festering in the background. From the start of the claim the native title process has allowed claimants whose connections to the claim area are questionable to come forward, leading to proceedings being dominated by this group to the detriment of the rights and interests of the proper Traditional Owners for the area. Unfortunately, despite our considerable effort and dialogue with the Land Council concerning this issue, the claim is continuing along its current path. While greater weight is placed on the wider Northern Kaanju identity and the claim being 'boxed up', core Northern Kaanju families for the claim area will continue to be marginalised in decision making processes to do with the claim and development proposals concerning the claim area. Put simply, our Native Title Representative Body is not listening to us, the primary Traditional Owners for the claim area, and the very people whose extensive knowledge of Indigenous law and custom and continuing connection to and engagement on homelands is supporting the claim.

Further, while the claim continues along its current path we see only problems for the formation of the $\mathrm{PBC}$ and for negotiations over major developments concerning the land such as the gas pipeline. We are firm in our determination that this impasse be broken and are currently seeking advice from the National Native Title Tribunal and lawyers on the best way to proceed in order to achieve the best outcome for the land and justice for the proper native title holders. ${ }^{26}$

\footnotetext{
24 M. Salmon, in Batavia Downs Steering Committee Meeting, Moreton Telegraph Station, 16 October 2001, CYLC minutes from meeting, p. 9.

25 While it is possible to seek some 'economic' rights and interests through the native title process, such rights and interests appear-given previous native title cases - to be essentially limited and 'backwards-looking'. As such, even if such rights were recognised in our case, they would provide a very limited basis for the current and future aspirations of Kaanju people living on our homelands.

26 There is not space in this paper to discuss these options. Our preference would be for the claim to be re-lodged with the Northern Kaanju claimant group comprising only those families actually from the area under claim. Otherwise we see the following alternative options: 1) withdraw from the current claim and lodge a rival claim to the same area; 2) as the claimant group in the current claim encompasses
} 
Through the Chuulangun Aboriginal Corporation we have also engaged directly with the corporation overseeing the negotiations over the gas pipeline to inform them of the issues and to ensure that the views are sought from the appropriate Traditional Owners for the land through which it is proposed the pipeline will pass. Similarly for sovereignty and compensation issues, the NTA needs to recognise that native title claims are considered on a case-by-case basis and as such claimant groups need to also be considered as such. While for a number of native title claims regionally based native title holding groups may be appropriate, this may not necessarily be the case for all native title claims. The NTA and process needs to recognise that for some claims locally based land holding bodies are the most appropriate scale for proper decision-making and better reflect traditional governance structures, law, custom, and continuing connection and engagement with country.

I would like to conclude with a few comments made by legitimate senior claimants during the claims process. In one instance, continuing debate over the issue of whether to extend the claim group to include another language group with connections to the northern area of the claim was met with the following response from a senior Kaanju Traditional Owner: 'But all the answers are gotten now and we need to finish this talk and get on with it'. ${ }^{27}$ This issue had been discussed in depth and resolved at a meeting held four months earlier. Another comment from the same Traditional Owner at the same meeting on the same issue was: 'Just make decision today-tired of talking all the time'. ${ }^{28}$

Finally, at a Steering Committee meeting held on country in 2001 a Kaanju Traditional Owner expressed his frustration over the NTA: 'All these Acts belong to the government but what about Aboriginal people. Can we produce a new Act that will combine everything? ${ }^{29}$ In response, an officer from the CYLC replied: 'We won't change the law but we can make progress through mediation and expedited native title process' ${ }^{30}$ Almost five years on we are still waiting to get our land back.

\footnotetext{
all the Northern Kaanju people from north of the Archer River, change the claim area to include the entire area of the Northern Kaanju homelands; 3) retain the existing claimant group, change the named applicants to include only people who are from the actual area under claim, and include a declaration in the application, and provide evidence for this in the Connection Report, that names the particular families that are actually from the area under claim and have the primary rights to the area in terms of decision making, land use, ownership and management, and notes that the other Northern Kaanju families are included as a courtesy, that is, that they are recognised but they do not necessarily have the primary rights to the area in terms of decision making, land use, ownership and management.

27 M. Sellars, in Batavia Downs Steering Committee Meeting, Cairns, Friday 18 January 2002, CYLC minutes from meeting, p 3 .

28 M. Sellars, in Batavia Downs Steering Committee Meeting, Cairns, Friday 18 January 2002, CYLC minutes from meeting, p. 4.

29 D. Claudie, in Batavia Downs Steering Committee Meeting, Moreton Telegraph Station, 16 October 2001, CYLC minutes from meeting, p. 4.

30 P. Blackwood, in Batavia Downs Steering Committee Meeting, Moreton Telegraph Station, 16 October 2001, CYLC minutes from meeting, p. 4.
} 


\section{References}

Bauman, T. and Williams, R. 2004. 'The business of process research issues in managing Indigenous decision-making and disputes in land', Research Discussion Paper No. 13, Native Title Research Unit, Australian Institute of Aboriginal and Torres Strait Islander Studies, Canberra.

Kaanju People and Salmon, M. 2000. Batavia Downs Aspirations Planning Report (BDAPR), Draft for Comment, unpublished report, November 2000, Balkanu Cape York Development Corporation, Cairns.

Cape York Land Council (CYLC) 1999. Batavia Native Title Application, Section A, CYLC, Cairns.

Chuulangun Aboriginal Corporation 2005. Kaanju Homelands Wenlock and Pascoe Rivers Indigenous Protected Area Management Plan, March 2005, Chuulangun Aboriginal Corporation, Chuulangun, Cape York Peninsula, Qld.

Claudie, D. 2004. “'Ancient but new": policy development from the ground up', Paper presented at the Community Engagement Programs for Improved Collaborative Indigenous Policy Development Conference, Cairns, 26-27 July.

Muir, K. 1998. "This Earth has an Aboriginal culture inside": recognising the cultural value of country', Land, Rights, Laws: Issues of Native Title, Issues Paper No. 23: 2-9, Native Title Research Unit, Australian Institute of Aboriginal and Torres Strait Islander Studies, Canberra.

Sinclair, I. 2003. Batavia Downs Land Evaluation Report, unpublished report, Catchment and Regional Planning, North Region, Department of Natural Resources and Mines, Atherton.

Smith, B. R. 2000. "Local" and "diaspora" connections to country and kin in central Cape York Peninsula', Land, Rights, Laws: Issues of Native Title, 2 (6): $1-12$.

Smith, B. R. 2005. 'We got our own management: local knowledge, government and development in Cape York Peninsula', Australian Aboriginal Studies, 2005 (2): 4-15.

Smith, B. R. 2006. Connection Report, Batavia Downs Native Title Claim, confidential first draft prepared for the Cape York Land Council, 16 January 2006.

Smith, B. R. and Claudie, D. 2003. 'Developing a land and resource management framework for Kaanju homelands, central Cape York', CAEPR Discussion Paper No. 256, Centre for Aboriginal and Economic Policy Research, The Australian National University, Canberra. 
Sullivan, P. 1997. 'Dealing with native title conflicts by recognising Aboriginal political authority', in D.E. Smith and J. Findlayson (eds), Fighting Over Country: Anthropological Perspectives, CAEPR Research Monograph No. 12, Centre for Aboriginal and Economic Policy Research, The Australian National University, Canberra. 